\title{
Application of Lemongrass and Cinnamon Pesticides on Rice Ear Bug (Leptocorisa oratorius Fabricius) in Padi Plant
}

\author{
Christina Salaki, Vivi Montong \\ Study Program of Plant Protection, Faculty of Agriculture, Sam Ratulangi University, North Sulawesi, Indonesia
}

\section{Email address:}

christinasalaki@ymail.com (C. Salaki)

\section{To cite this article:}

Christina Salaki, Vivi Montong. Application of Lemongrass and Cinnamon Pesticides on Rice Ear Bug (Leptocorisa oratorius Fabricius) in Padi Plant. International Journal of Applied Agricultural Sciences. Vol. 5, No. 5, 2019, pp. 105-108. doi: 10.11648/j.ijaas.20190505.11

Received: July 24, 2019; Accepted: August 13, 2019; Published: September 4, 2019

\begin{abstract}
Lemongrass and cinnamon plant are known holding active compounds that can be used as raw materials of plant pesticides. It is related with their ability to kill, extrude, and prevent the pest insects from feeding, including rice ear bug Leptocorisa oratorius, one of the dangerous and uncontrollable padi plant pests. This study was aimed at finding the best formula of lemongrass and cinnamon-based plant pesticide formulation to control rice ear bug L. oratorius, to know the killing ability, and to do the pathogenicity test. It was carried out in a greenhouse of Pest and Disease Department, Faculty of Agriculture, UNSRAT, Manado, in March to September 2018. The treatments consisted of mixed lemongrass and cinnamon at concentrations of $2 \mathrm{cc} / \mathrm{L}, 4 \mathrm{cc} / \mathrm{L}, 6 \mathrm{cc} / \mathrm{L}, 8 \mathrm{cc} / \mathrm{L}, 10 \mathrm{cc} / \mathrm{L}$, and control. Parameters observed were nymph mortalities at 12, 24, 48, and 72 hours after application. The treatments were administered by spraying the insect, the plant, and the insect on the plant. Results showed that spraying the insect with rice ear bug pesticide could result in $36.7-86.7 \%$ of mortality and with cinnamon pesticide could kill 56.7 - 93.3\%, spraying the plant with rice ear bug and cinnamon pesticides could cause 3.3 $36.7 \%$ and $6.7-40 \%$ of mortality, respectively, while spraying the insect on the plant could make $60-100 \%$ of mortality using rice ear bug pesticide and $70-100 \%$ of mortality using cinnamon pesticide at 12 and 72 hours after the application.
\end{abstract}

Keywords: Formulation, Pathogenicity, Insect, Mortality, Spraying Method

\section{Introduction}

Paddy is an important agricultural commodity in Indonesian people's life and has become priority in agricultural program development. Therefore, padi planting has still been the backbone of rural economy up to now [1]. One of the constraints in growing padi in Indonesia is invasion of rice ear bug L. oratorius (Hemiptera; Alydidae). This insect has become important pest for padi plant. It is easily recognized from the form with body length of $2 \mathrm{~cm}$, grey-brown colour, and has proboscis to suck the plant liquid. L. oratorius sucks the pant liquid of panicle (paniculae) and padi fruit at maturing phase and makes the plant lack of nutrient and turn yellow (chlorosis), and gradually weaken. The name of the insect has exhibited its defensive mechanism by releasing stinky unpleasant aroma [2].

L. oratorius is cause of production loss. Invasion of one individual per night per week can cause $27 \%$ production loss. Maintaining padi productivity in Indonesia from decline needs the way to prevent the invasion of this insect pest, one of which is the use of essential oil active compound-based plant pesticide [3, 4]. Essential oil is one of the plant materials derived from leaf, flower, stem, seeds, and flower bud. One of the promising essential oil as plant insecticide is lemongrass and cinnamon oil [5-7].

This plant contains about $32-45 \%$ citronella, $10-12 \%$ geraniol, 11-15\% citronellol, 3-8\% geranyl acetate, 2-4\% citronellal acetate, and some sesquiterpenes. Lemongrass can control flour beetles (Tribolium sp), weevils (Sitophilus sp), cowpea weevils (Callosobruchus sp), nematode (Melodogyne sp), and fungi [8-9]. It is also potentially used as plant pesticide because lemongrass contains methyl heptanone that is repellent to insects [10-12] insecticidal to flies $[13,14]$, and can be used to control the mosquito bugs Helopeltis antonii [15-17]. 
Citronellol content of lemongrass oil [18] is toxic and reduces the reproductive ability of insects. Citronellal compound is a contact toxin and causes dehydration, so that the insect will dehydrate and die [19], besides lemongrass oil aroma has efficacy to exclude mosquitoes [20, 21]. Lemongrass oil at concentration of $2.5 \%$ is efficient to reduce number of flies resting and their live larvae on the dead carp [22]. Laboratory experiment [23] shows that at the concentration of $0.4 \%$ lemongrass oil can reduce $55-66 \%$ egg placement of Helicoverpa armigera.

Cinnamon (Cinnamomum burmanii) belongs to potential plant to be developed as source of raw material of plant pesticide industry since it contains numerous toxic components to insects as anti-feedant (affecting feeding) and antihormonal (disturbing hormone formation). Major content of cinnamon is cinnamaldehyde [24].

Essential oil of cinnamon wastes is evident to be able to prevent plant pathogenic fungi, such as Fusarium oxysporum, F. sp vanillae as cause of rotten trunk disease of vanilla, F. oxysporium f. sp. Zingiberi as cause of rotten rhizome of ginger, and Phytoptora capsici as cause of rotten trunk of pepper plant. In relation with the potential of plantbased pesticides to control plant pests and diseases $[17,25$, 26]. This study was conducted in order to obtain the best plant insecticide formula of lemongrass and cinnamon oil that effectively control the attack of $L$. oratorius on padi plant. This study was aimed to know the lethal concentration of lemongrass oil and cinnamon oil based plant pesticide against $L$. oratorius on padi plant.

\section{Research Methodology}

The experiment was carried out in the greenhouse of Plant Pest and Disease Department, Faculty of Agriculture UNSRAT Manado from March to September 2018. The study used big wire cage, small wire cage, polybag, 30 days old-padi plant, L. oratorius nymphs, lemongrass and cinnamon pesticides, hand sprayer, and other materials.

The test insects $L$. oratorius were collected from padi plant production centre. Eggs and nymphs were reared and multiplied on padi plant placed in the wire cage. The nymphs were taken from the third instar nymphs of the second imago generation.

The study used with 6 treatments and 4 replications. Treatments employed 2 types of pesticides, cinnamon and lemongrass at the concentration of $2 \mathrm{cc} / \mathrm{L}, 4 \mathrm{cc} / \mathrm{L}, 6 \mathrm{cc} / \mathrm{L}, 8$ $\mathrm{cc} / \mathrm{L}$, and $10 \mathrm{cc} / \mathrm{L}$, and water as control.

Pesticide application employed 3 techniques: 1) Insect spraying. Ten test insects were placed in the flask and sprayed with sufficient amount of pesticide, then invested on the padi plant in the cage; 2) Plant spraying. Entire padi plants were evenly sprayed with pesticide solution and placed in the cage. After wind-dried, 10 test insects were placed on each individual plant; 3) Spraying insects on plant. Thirty insects were invested into the cage of padi plant and sprayed evenly with pesticide. Parameter observed was nymph mortality at 12, 24, 48, and 72 hours after administration. Mortality was calculated following Abbot [27] as follows:

$$
\mathrm{M}=\frac{A}{B} x 100
$$

Where $\mathrm{M}=$ mortality, $\mathrm{A}=$ number of insects die, and $\mathrm{B}=$ number of test insects

\section{Results and Discussion}

\section{A. Lemongrass application to L. oratorius}

Mortality level of $L$. oratorius seems to be higher in direct spray on the insect than on the plant (Table 1). The pesticide works as contact toxin and nerve toxin. It enters through body pores or mouth together with food. This compound then goes into the digestive organ and absorbed by the intestinal wall and translocated to the nerve centre so that the nerve system is disturbed and affects the equilibrium of nerve system ions and kills the insect [28].

Table 1. Mortality of rice ear bug (L. oratorius) treated with lemongrassbased pesticide.

\begin{tabular}{|c|c|c|c|c|c|}
\hline \multirow{2}{*}{ Method } & \multirow{2}{*}{$\begin{array}{l}\text { Concentration } \\
(\mathrm{cc} / \mathrm{L})\end{array}$} & \multicolumn{4}{|c|}{ Mortality (\% } \\
\hline & & $12 \mathrm{~h}$ & $24 \mathrm{~h}$ & $48 \mathrm{~h}$ & $72 \mathrm{~h}$ \\
\hline \multirow{6}{*}{$\begin{array}{l}\text { Insect } \\
\text { spraying }\end{array}$} & $2 \mathrm{cc} / \mathrm{L}$ & 0 & 13.3 & 20 & 36.7 \\
\hline & $4 \mathrm{cc} / \mathrm{L}$ & 0 & 20 & 33.3 & 40 \\
\hline & $6 \mathrm{cc} / \mathrm{L}$ & 10 & 36.7 & 50 & 63.3 \\
\hline & $8 \mathrm{cc} / \mathrm{L}$ & 13.3 & 53.3 & 60 & 73.3 \\
\hline & $10 \mathrm{cc} / \mathrm{L}$ & 26.7 & 60 & 73.3 & 86.7 \\
\hline & Control & 0 & 0 & 0 & 0 \\
\hline \multirow{6}{*}{$\begin{array}{l}\text { Plant } \\
\text { spraying }\end{array}$} & $2 \mathrm{cc} / \mathrm{L}$ & 0 & 0 & 0 & 3.3 \\
\hline & $4 \mathrm{cc} / \mathrm{L}$ & 0 & 0 & 0 & 6.7 \\
\hline & $6 \mathrm{cc} / \mathrm{L}$ & 0 & 0 & 3.3 & 20 \\
\hline & $8 \mathrm{cc} / \mathrm{L}$ & 3.3 & 3.3 & 6.7 & 26.7 \\
\hline & $10 \mathrm{cc} / \mathrm{L}$ & 3.3 & 6.7 & 26.7 & 36.7 \\
\hline & Control & 0 & 0 & 0 & 0 \\
\hline \multirow{6}{*}{$\begin{array}{l}\text { Insect } \\
\text { spraying on } \\
\text { plant }\end{array}$} & $2 \mathrm{cc} / \mathrm{L}$ & 3.3 & 20 & 53.3 & 60 \\
\hline & $4 \mathrm{cc} / \mathrm{L}$ & 3.3 & 26.7 & 66.7 & 76.7 \\
\hline & $6 \mathrm{cc} / \mathrm{L}$ & 10 & 50 & 73.3 & 83.3 \\
\hline & $8 \mathrm{cc} / \mathrm{L}$ & 13.3 & 60 & 80 & 93.3 \\
\hline & $10 \mathrm{cc} / \mathrm{L}$ & 16.7 & 70 & 93.3 & 100 \\
\hline & Control & 0 & 0 & 0 & 0 \\
\hline
\end{tabular}

Other factor affecting the mortality of $L$. oratorius beside spraying method application is active compound. The presence of essential oil in lemongrass, such as citronella and limonoid, influences the movement of the insect L. oratorius [29]. The higher the concentration of essential oil sprayed is, the faster the pesticide kill the insects.

Observations showed the pesticide spray made the insect's limb be stationary and stiff. It could result from that the essential oil of the lemongrass enters through the cuticle of L. oratorius. As intestinal toxin, limonoid could enter the digestive tract through digestive tract. The pesticide will go into the digestive organ and disturb the metabolism of the insect so that the insect will lack of energy for living activities and kill the insect. The essential oil could directly penetrate the integument, trachea, or other sensor glands [29].

Lemongrass leaf contains saponin, flavonoid, alkaloid, polyphenol, and citronella that were potential to kill insects. 
Besides these compounds are toxic, they could also inhibit the appetite. Similar findings are also reported in previous studies that the active compounds in the essential oil function as insect killer and reduce the insect reproductive ability [3032]. The concentration of lemongrass-based pesticide at 1$7 \%$ can kill $81.15-98.06 \%$ of aphid insects [30].

Citronella content in the lemongrass oil is repellent at low concentration and insecticidal at high concentration. Concentration of $4.000 \mathrm{ppm}$ could kill the mosquito bug Helopeltis spp., cacao fruit sucking pest insects [15]. Besides being insect repellent, the citronella works as contact toxin. Contact toxin of citronella works to inhibit acetylcholinesterase enzyme so that phosphorylation of amino acid serine occurs. Poisoning symptoms appears due to acetylcholine hoarding that causes the central nerve system disturbance, seizures, respiration failure, and mortality [15].

B. Cinnamon pesticide application on L. oratorius

Cinnamon pesticide could cause $>70 \%$ mortality at the concentration of $4 \mathrm{cc} / \mathrm{L}, 6 \mathrm{cc} / \mathrm{L}, 8 \mathrm{cc} / \mathrm{L}$, and $10 \mathrm{cc} / \mathrm{L}$ at 72 hours, and it is much higher than that in control treatment.

Table 2. Mortality of rice ear bug (L. oratorius) treated with cinnamonbased pesticide.

\begin{tabular}{llllll}
\hline \multirow{2}{*}{ Method } & Concentration & \multicolumn{3}{l}{ Mortality } \\
\cline { 3 - 6 } & $(\mathbf{c c} / \mathbf{L})$ & $\mathbf{1 2} \mathbf{h}$ & $\mathbf{2 4} \mathbf{h}$ & $\mathbf{4 8} \mathbf{~ h}$ & $\mathbf{7 2} \mathbf{~}$ \\
\hline \multirow{4}{*}{ Insect } & $2 \mathrm{cc} / \mathrm{L}$ & 0 & 20 & 50 & 56.7 \\
spraying & $4 \mathrm{cc} / \mathrm{L}$ & 3.3 & 43.3 & 56.7 & 70 \\
& $6 \mathrm{cc} / \mathrm{L}$ & 10 & 53.3 & 70 & 86.7 \\
& $8 \mathrm{cc} / \mathrm{L}$ & 10 & 63.3 & 90 & 93.3 \\
& $10 \mathrm{cc} / \mathrm{L}$ & 13.3 & 66.7 & 93.3 & 93.3 \\
& $\mathrm{Control}$ & 0 & 0 & 0 & 0 \\
& $2 \mathrm{cc} / \mathrm{L}$ & 0 & 0 & 0 & 3.3 \\
Plant & $4 \mathrm{cc} / \mathrm{L}$ & 0 & 0 & 0 & 6.7 \\
spraying & $6 \mathrm{cc} / \mathrm{L}$ & 0 & 0 & 3.3 & 10 \\
& $8 \mathrm{cc} / \mathrm{L}$ & 3.3 & 3.3 & 16.7 & 26.7 \\
& $10 \mathrm{cc} / \mathrm{L}$ & 3.3 & 6.7 & 30 & 40 \\
& $\mathrm{Control}$ & 0 & 0 & 0 & 0 \\
& $2 \mathrm{cc} / \mathrm{L}$ & 3.3 & 40 & 60 & 70 \\
Spraying & $4 \mathrm{cc} / \mathrm{L}$ & 6.7 & 46.7 & 66.7 & 80 \\
insect on & $6 \mathrm{cc} / \mathrm{L}$ & 6.7 & 53.3 & 70 & 86.7 \\
plant & $8 \mathrm{cc} / \mathrm{L}$ & 13.3 & 66.7 & 80 & 93.3 \\
& $10 \mathrm{cc} / \mathrm{L}$ & 26.7 & 76.7 & 90 & 100 \\
& $\mathrm{Control}$ & 0 & 0 & 0 & 0 \\
\hline
\end{tabular}

Results showed that the mortality of $L$. oratorius varied at different concentration with the highest at $10 \mathrm{cc} / \mathrm{L}$ in insect on plant spraying method and the lowest in control treatment (Table 2). This study also found that higher concentration level increased the toxin content of the cinnamon extract indicated with higher mortality of $L$. oratorius. Previous study has found that cinnamon contains anti-feedant compound that reduces the appetite and the reproductive ability [33]. The use of $1 \%(\mathrm{~b} / \mathrm{v})$ cinnamon-based pesticide can kill $95.7 \%$ pest insects $[34,35]$.

Cinnamon oil-based pesticide at the concentration of $0.8 \%$ is effective to control Helopelthis theivora with killing ability of $30 \%[16,36]$. Cinnamon oil has also insecticidal effect on the biological aspect of Aspidomorpha milliaris [24].
The examination of cinnamon extract on $L$. oratorius could influence the physiology of the insect growth indicated by the behaviour and the feeding activity. The insect growth inhibition feeding on the cinnamon extract-containing plant could result from energy allocation for toxic compound detoxification. Inhibition of protein synthesis also occurs due to the disturbance of protein breakdown of the food that causes increased mortality during the molting process.

\section{Conclusion}

The use rice ear bug and cinnamon plant pesticides could kill the pest $L$. oratorius. The experiment showed that $10 \%$ concentration resulted the highest mortality of the pest, while the most effective method used $2 \mathrm{cc} / \mathrm{L}$ at 72 hours and could give $\geq 50 \%$ mortality. However, the use of these types of pesticides needs to be tested in the field.

\section{References}

[1] P. M. Sirrapa (2011). Study on padi culture technology improvement through the use of superior seeds and Legowoplanting system to increase padi productivity for food selfsufficience. J. Budidaya Pertanian, 7 (2): 79-86. [in Indonesian]

[2] Z. F. Rozi, Y. Febrianti, Y. Telaumbanua (2018). Potential of Diascurea hispida $L$ juice as bio-insecticide of rice ear bug Leptocorisa oratorius on padi plants Oryza sativa L. J. Biogenesis. Vol. 6, No. 1: 18-22. [in Indonesian]

[3] A. F. Sitompul, O. Syahrial, Y. Pangestiningsih (2014). The effectivity test of plant insecticide on the mortality of Leptocorisa acuta T (Hemiptera; Alydidae P) on padi plants (Oryza sativa L.) in the greenhouse. Program Studi Agroekoteknologi, Fakultas Pertanian. Universitas Sumatera Utara. Medan. J. Agroekoteknologi ISSN No. 2337-6597. Vol. 2 (3): 1075-1080. [in Indonesian]

[4] Rianiyati (2013) The influence of plant pesticide combination application on the production of padi plant (Oryza sativa L.) Varietas Inpara-3 of The System of Rice Intensification (SRI). Jurnal Bioplantae. Vol. 2 No. 4.: 169-174. ISSN: 2302-6472. [in Indonesian]

[5] S. B. Moraes, W. B. Moraes, G. Camara, K. S. Maciel, P. A. Lima, A. Ferreira, R. S. Alexandre and J. C. Lopes (2018). Cinamon and citronella essential oil in the in vitro control of the fungi Aspergilus sp. and Sclerotinia sclerotiorum. African Journal of Agricultural Research. 13 (35: 1811-1815. August, 2018.

[6] R. Samarasekera, K. S. Kalhari, and L. S. Weerasinghe (2006). Insecticidal activity of essential oils of Ceylon Cinomomum and Cymbopogon species against Musca domestica. Journal of Essential Oil Research. 18 (3): 352-354.

[7] H. Idris and Nurmansyah (2017). Plant pesticide of cinnamon and lemongrass for pest Nilam Pachyzancla stultalis control. Buletin Penelitian Tanaman Rempah dan Obat. Vol. 28 No. 2: 163-170. [in Indonesian]

[8] M. Isnaini, E. R. Pane, S. Wiridianti (2015). Testing of several plant insecticides on the rice bug (Sitophilus oryzae L). Jurnal Biota. Vol. 1: 1-8. [in Indonesian] 
[9] M. A. Ootani, D. R. Brito, G. P. S. Maciel, L. A. Lopes, and R. W. S. Aguiar (2016). Effect of essential oil and Citronellal compound on bean seeds stored microflora. Revista Verde de Agroecologia e Desenvolvimento Sustentavel. 11 (1): 49-56.

[10] R. W. Geetha and A. Roy (2014). Essential oil repellents. A short review. International Journal Drug Development and Research 6 (2), 20-27.

[11] C. S. Rante, D. T. Sembel, E. R. M. Meray, M. M. Ratulangi, M. F. Dien, and D. S. Kandowangko (2013). The use of plant insecticide to control pests on tomato plant. J. Eugenia 19 (2): 97-102. [in Indonesian]

[12] Supriadi (2013). Optimization of various pesticides utilization to control plant pests and diseases. J. Penelitian dan Pengembangan Pertanian 32 (1): 1-9. [in Indonesian]

[13] Ch. Salaki and J. Pelealu (2012). The use of Barringtonia asiatica and Annona muricata on disease vector insects on chili plant. J. Eugenia Vol 18 (1): 22-28. [in Indonesian]

[14] L. Tigaw and Ch. Salaki (2015). Effectivity test of garlic and tobacco extract as bio-insecticide on green peach aphid Myzus persicae on ada tanaman cabai. J. Eugenia Vol. 21 (3): 135141 [in Indonesian]

[15] Nurmansyah (2011). The effectivity of lemongrass on sucking pest of cocco plant Helopeltis antonii. Bul. Littro. 22 (2): 205213. [in Indonesian]

[16] M. Darwis and W. R. Atmadja (2010). [The use of 10 medicinal and aromatic plants for pest Helopeltis theivora Watch prevention.] In; Prosiding. Seminar Nasional VI. Peranan Entomology dalam Mendukung Pengembangan Pertanian Ramah Lingkungan dan Kesehatan Masyarakat. Bogor, Perhimpunan Entomologi Indonesia. p. 328-336. [in Indonesian]

[17] Z. Jiang, H. Jiang and P. Xie (2013). Antifungal activities against Sclerotinia cslerotiorum by Cinnamomum cassia oil and its main components. J. essential oil Research 25 (6): 444-451.

[18] Rohimatum and I. W. Laba (2013). The effectivity of lemongrass oil and clove oil insecticides on pepper pests. Bul. Littro. 24 (1): 26-34.

[19] F. M. Howlett (1912). The effect of oil of citronella on two species of Dacus. Transactions of the Royal Entomological Society of London. 60 (2): 412-418.

[20] C. Kongkaew, I. Sakunrag, N. Chayakunapruk and A. Tawatsin (2011). Effectiveness of citronella preparations in preventing mosquito bites; Systematic Review of Controlled Laboratory Experimental Studies. Tropical Medicine \& International Health. 16 (7): 802-810.

[21] C. Kongkaew, L. Sakunrag, N. Chaiyakunapruk, and A. Tawatsin (2011). Effectiveness of citronellain preventing mosquito bites. Tropical Medicine and International Health 16 (7): $802-810$

[22] L. R. Lindsay, G. A. Surgeoner, J. D. Heal and G. J. Gallivan (1996). Evaluation on the efficacy of 3\% citronella candles and 5\% Citronella incense for protection against field populations of Aedes mosquitoes. J. the American Mosquito Control Association. 12 (2 Pt 1): 293-294.

[23] W. R. Atmadja (2010). The use of shrub, clove, lemongrassbased insecticides for worm Spodoptera litura prevention.
Prosiding Seminar Nasional VI Peranan Entomologi dalamn Mendukung Pengembangan Pertanian Ramah Lingkungan dan Kesehatan Masyarakat. Indonesian Enthomology Association, Bogor Branch. p. 191-200. [in Indonesian]

[24] H. Idris (2014). Effect of cinnamon-based bio-insecticide on the biological aspects of Aspidomorpha milliaris F. Buletin Ilmiah Eka Sakti 26 (1): 68-77. [in Indonesian]

[25] Nurmansyah (2006). The effect of plant and solvents administration on the capability of cinnamon waste oil-based pesticide antifungal. Jurnal Dinamika Pertanian. 21 (2), 115120 [in Indonesian]

[26] M. S. Khan and I. Ahmad (2011). In vitro antifungal, antielastase and anti-keratinase activity of essential oil of Cinnamomum, Syzygium and Cymbopogon-species against Aspergillus fumigatus and Trichophyton rubrum, Phytomedicine 19 (1): 48-55.

[27] W. S. Abbott (1925). A Method of Computing the Effectiveness of an Insecticide. J. Am. Mosq. Control. Assoc. 1987. 3; 302-303.

[28] Nakahara, Kazuhiko, N. S. Alzoreky, T. Yoshihashi, H. T. Nguyen and G. Trakoon-tivakorn (2013). Chemical composition and antifungal activity of essential oil from Cymbopogon nardus (Citronella Grass). Japan Agricultural Research Quarterly. 37 (4): 249-252.

[29] R. O. B. Wijesekera (1973). The chemical composition and analysis of Citronella oil. J. the Natural Science Council of Sri Lanka. 1: 67-81.

[30] C. L. Abramson, P. A. Wanderley, M. J. A. Wanderley, A. J. S. Mina, O. B. D. Souza, and C. Edgar (2006). Effective essential oil from citronella and alfazema on Fennel Aphids Hyadaphis foeniculli passerine (Hemiptera: Aphididae) and its predator Cycloneda. sanguinea (coleopteran; Coccinelidae). American Journal of Enviromental Science 3 (1): 9-10.

[31] A. Ahmad, M. Kaleem, Z. Ahmed, and H. Shafig (2015). Therapeutic potential of flavonoids and their mechanism of action against microbial and viral infection $-\mathrm{A}$ review. Food Research International 77 (2): 221-235.

[32] M. A. Ootani, R. W. Aguiar, A. C. Ramos, D. R. Brito, J. B. D. Silva, and J. P. Cajazeira (2013). Use of essential oil in agriculture. J. Biotektonology and Biodiversity 4 (2): 162175.

[33] D. Ganjewala (2009). Cymbopogon essential oils; chemical compositions and bioactivities. International journal of essential oil therapeutics. 3 (2-3): 56-65.

[34] H. Idries (2014). The effect of cinnamon bio-insecticide on the biological aspects of Aspidomorpha milliaris F. Buletin Ilmiah Eka Sakti. 26 (1): 68-77. [in Indonesian]

[35] Clemente, M. Aparecido, C. M. Monteiro, M. G. coralik, F. T. Gomes, M. C. Prata, and E. Daemon (2010). Acaricidal activity of the essential oils from Eucalyptus citriodora and Cymbopogon nardus on larvae of Amblyomma cajennense (Acari; Ixodidae) and Anocentor nitens (Acari; Ixodidae). Parasitology Researh 107 (4): 987-992.

[36] H. Idris (2014). Plant insecticide formula for pest Pachyzancla stultalis control in patchouli plant. Bul. Littro. 25 (1): 69-76. [in Indonesian] 